\title{
ANALISIS PENGENDALIAN INTERNAL DALAM PEMBERIAN KREDIT KOPERASI SIMPAN PINJAM (Studi Kasus Koperasi Bobato Unit Sofifi)
}

\author{
Jufri Togubu ${ }^{1}$, Adriana Katty ${ }^{2}$ \\ 1Jurusan Akuntansi Fakultas Ekonomi Universitas Bumi Hijrah Tidore \\ (Email: upitogubu@gmail.com) \\ ${ }^{2}$ Jurusan Akuntansi Fakultas Ekonomi Universitas Bumi Hijrah Tidore \\ (Email: adrianakatty@gmail.com)
}

\begin{abstract}
ABSTRAK
Kasus kredit bermasalah dan kredit macet pada lembaga keuangan. Oleh karena itu, keamanan atas pemberian kredit harus benar-benar diperhatikan oleh koperasi. Karena salah dalam pengambilan keputusan akan menyebabkan terjadinya kredit macet yang akan merugikan koperasi. Permasalahan ini bisa dihindari dengan adanya suatu pengendalian intern yang memadai dalam bidang perkreditan. Dengan kata lain diperlukan suatu pengendalian internal yang dapat menunjang efektivitas sistem pemberian kredit. Dengan terselenggaranya pengendalian internal yang memadai dalam bidang perkreditan, berarti menunjukkan adanya sikap kehati-hatian pada koperasi terutama dalam hal memberikan kredit.

Tujuannya adalah untuk mengetahui hal-hal apa saja yang harus dipertimbangkan dalam menyetujui kredit, penyebab kredit macet dan cara mengatasinya serta keefektifan pengendalian internal dalam pemberian kredit. Dengan menggunakan metode penelitian pengumpulan data dari berbagai sumber baik dari buku-buku, majalah, brosur dan data-data dari Koperasi Bobato Unit Sofifi. Selain itu juga dengan melakukan wawancara kepada nara sumber dan melakukan pengamatan pada obyek penelitian.

Dengan hasil penelitian dapat diketahui keefektifan pengendalian internal dengan penerapan prinsip 5C dan 7P, yang lebih menekankan pada Character, Collateral, Prospect, Payment dan Personality. Biasanya kegagalan kredit yang terjadi itu karena kelalaian pihak koperasi dalam menganalisa kredit yang akan disalurkan. Untuk mengatasinya dilakukan perpanjangan jangka waktu kredit, memperpanjang jangka waktu angsuran, penundaan pembayaran bunga sampai penurunan suku bunga. Kalau dengan cara itu masih sulit, jalan terakhir yang dilakukan dengan penyitaan barang jaminan. Sedang pengendalian internal yang dilakukan yaitu dengan menerapkan elemen-elemen pengendalian internal dan pemisahan tugas pada setiap bagian, terutama pada bagian kredit.
\end{abstract}

Kata kunci : pengendalian internal dalam kredit. 


\section{PENDAHULUAN}

Perkembangan dalam usaha koperasi sangat dipengaruhi oleh banyaknya debitur yang dimilki. Sehingga dari tahun ke tahun koperasi memiliki peningkatan dalam keanggotaan maka dapat dikatakan bahwa koperasi tersebut mengalami penurunan. Begitu pula dengan tingkat keuntungan koperasi, semakin banyak debitur maka tingkat keuntungan pada koperasi otomatis mengalami peningkatan dan jika debitur berkurang maka keuntungan yang diperoleh menurun.

Pemberian kredit merupakan suatu bentuk usaha yang dilakukan oleh koperasi untuk mengolah modal yang dimilki dari hasil donasi dan simpanan anggota untuk memberikan pinjaman kepada anggota dengan mengambil keuntungan dari pembayaran bunga dari anggota yang melakukan pinjaman. Hal ini yang harus diperhatikan oleh koperasi dimana dalam memberikan pinjaman atau kredit koperasi harus memperhatikan faktor-faktor yang meyakinkan dalam pemberian kredit untuk memastikan kelancaran pembayaran kredit.

Perkembangan Nasabah Koperasi Bobato Unit Sofifi

\begin{tabular}{|c|l|l|c|}
\hline Tahun & Jumlah Nasabah & Jumlah peminjam & Persentase \% \\
\hline 2013 & 334 Nasabah & 943.500 .000 & 24.88 \\
\hline 2014 & 420 Nasabah & 1.249 .500 .000 & 32.96 \\
\hline 2015 & 520 Nasabah & 1.598 .500 .000 & 42.16 \\
\hline Total & 1.274 Nasabah & 3.791 .500 .000 & 100 \\
\hline
\end{tabular}

Sumber : Koperasi Bobato Unit sofifi ( telah diolah 2016 )

Sekarang banyak sekali terjadi kasus kredit bermasalah dan kredit macet pada lembaga keuangan. Oleh karena itu, keamanan atas pemberian kredit harus benar-benar diperhatikan oleh koperasi. Karena salah dalam pengambilan keputusan akan menyebabkan terjadinya kredit macet yang akan merugikan koperasi. Permasalahan ini bisa dihindari dengan adanya suatu pengendalian internal yang memadai dalam bidang perkreditan. Dengan kata lain diperlukan suatu pengendalian internal dalam penerapan 5C (Character, Capacity, Capital, Collateral, Condition of Economic) dan 7P ( Personality, Party, Purpose, Prospect, Payment, Profibility, Protection) yang dapat menunjang efektivitas sistem pemberian kredit. Dengan terselenggaranya pengendalian internal yang memadai dalam bidang perkreditan, berarti menunjukkan adanya sikap kehati-hatian pada koperasi terutama dalam hal memberikan kredit.

Beberapa penelitian terdahulu tentang Analisis pengendalian internal prosedur dalam pemberian kredit koperasi adalah, penelitian Sitti Maunah (2010) dengan judul Analisis Pengendalian Internal dalam Sistem Pemberian Kredit Pada Koperasi Simpan Pinjam Gradiska Candirejo. Dalam penelitian ini penulis menggunakan jenis penelitian deskriptif. Dengan hasil penelitian dapat diketahui keefektifan pengendalian internal dengan penerapan prinsip 5C dan 7P, yang lebih menekankan pada character, Collateral, Prospect, Payment, dan Personality. Sedangkan pengendalian internal yang dilakukan yaitu dengan menerapkan elemen-elemen pengendalian internal yang dilakukan yaitu dengan menerapkan elemen-elemen pengendalian internal dan pemisahan tugas pada setiap bagian, terutama pada bagian kredit. 
Pengendalian internal adalah proses yang dapat dipengaruhi manajemen dan karyawan dalam menyediakan secara layak suatu kepastian mengenai prestasi yang diperoleh secara objektif dalam penerapannya tentang bagian laporan keuangan yang dapat dipercaya, diterapkannya efisiensi dan efektivitas dalam kegiatan operasional perusahaan dan diterapkannya peraturan dan hukum yang berlaku agar ditaati oleh semua pihak.

\section{METODE PENELITIAN Jenis penelitian}

Penelitian ini mengunakan metode deskriptif untuk melukiskan secara sistematis fakta atau karakteristik populasi tertentu atau bidang tertentu, dalam hal ini bidang secara aktual dan cermat. Metode deskriptif bukan saja menjabarkan (analitis), akan tetapi juga memadukan. Bukan saja melakukan klasifikasi, tetapi juga organisasi. Metode penelitian deskriptif pada hakikatnya adalah mencari teori, bukan menguji teori. Metode ini menitikberatkan pada observasi dan suasana alamiah.

\section{Lokasi dan Waktu Penelitian}

Tempat yang dipilih sebagai lokasi penelitan sesuai dengan judul penelitian dan sangat relevan dengan permasalahan yang diajukan adalah Koperasi Simpan Pinjam Bobato Unit Sofifi Sedangkan waktu penelitian dan penyusunan laporan akhir diperkirakan menyita waktu selama tiga bulan.

\section{Jenis dan Sumber Data}

Jenis data yang digunakan dalam penelitian ini adalah data primer dan data sekunder, Observasi, dan Studi Pustaka.

\section{Populasi dan Sampel Penelitian}

Adapun yang menjadi populasinya adalah Koperasi Bobato Unit Sofifi. Sampel adalah bagian dari populasi, dari penelitian ini sampel yang diambil adalah prosedur pemberian kredit Koperasi Bobato Unit Sofifi.

\section{Teknik Analisis Data}

Untuk menghasilkan dan memperoleh data yang akurat dan objektif penelitian ini mengunakan teknik analisis data kualitatif dengan cara analisis konteks dari telah pustaka dan analisis pernyataan dari hasil wawancara dari informan.

\section{HASIL PENELITIAN DAN PEMBAHASAN Hasil Penelitian}

Koperasi Bobato berdiri pada tanggal 26 oktober 1996 di Topo dengan Badan Hukum No 284/BH/PAD/KWK.25/X/1996. Kemudian pada tanggal 29 Noverber 2004 Koperasi Bobato membuka cabang di sofifi yang beralamat di desa Bukit Durian Dusun Bukulasa.Data karyawan koperasi Bobato Unit Sofifi pada tahun 2013 sebanyak 6 orang,yang terdiri dari 2 pria dan 4 wanita dengan nasabah sebanyak 334 nasabah,pada tahun 2014 jumlah pegawai koperasi unit sofifi sebanyak 7 orang pria 2 dan wanita5 orang dengan nasabah sebanyak 420 nasabah,pada tahun 2015 sebanyak 9 Orang yang terdiri Pria 3 orang dan Wanita 6 orang dengan nasabah sebanyak 520 nasabah. Tabel di bawah ini bisa kita bisa lihat bahwa koperasi Bobato Unit sofifi mengalami peningkatan. 
Perkembangan Anggota Koperasi Bobato Unit Sofifi

\begin{tabular}{|l|l|l|c|}
\hline Tahun & Jumlah Nasabah & $\begin{array}{l}\text { Jumlah } \\
\text { peminjam }\end{array}$ & Persentase \% \\
\hline 2013 & 334 Nasabah & 943.500 .000 & 24.88 \\
\hline 2014 & 420 Nasabah & 1.249 .500 .000 & 32.96 \\
\hline 2015 & 520 Nasabah & 1.598 .500 .000 & 42.16 \\
\hline Total & $\mathbf{1 . 2 7 4}$ Nasabah & $\mathbf{3 . 7 9 1 . 5 0 0 . 0 0 0}$ & $\mathbf{1 0 0}$ \\
\hline
\end{tabular}

Sumber : Koperasi Bobato Unit Sofifi, 2016

Pada Tabel diatas menunjukan bahwa perkembangan nasabah koperasi bobato unit sofifi selama 3 tahun mencapai peningkatan yang begitu signifikan,karena pada tahun 2013 angka nasabah sebanyak 334 nasabah dengan jumlah pinjaman sebanyak 24.88\% atau Rp.943.500.000,pada tahun 2014 angka nasabah meningkat menjadi 420 nasabah dengan total pinjaman sebesar $32.96 \%$ atau Rp.1.249.500.000,sedangkan pada tahun 2015 angka nasabah semakin meningkat dengan jumlah nasabah sebanyak 520 nasabah dengan pinjaman $42.16 \%$ atau Rp.1.598.500.000.

\section{PEMBAHASAN}

Dilihat dari praktek sebenarnya prosedur pemberian kredit pada Koperasi Bobato Unit Sofifi melayani jasa pemberian kredit dari anggota maupun calon anggota. Prosedur pemberian kredit yang dilakukan melalui langkah-langkah yang sangat membantu dalam pengendalian pemberian kredit sehingga bisa mengatasi masalah yang timbul khusunya bagi pengurus dalam menyetujui permohonan kredit anggota atau calon anggota yang mengajukan pinjaman kredit tersebut.

\section{Sistem Pengendalian Internal dalam Kredit}

Penyebab utama terjadinya kredit macet ini adalah terlalu mudahnya koperasi memberikan pinjaman, sehingga penilaian kredit kurang cermat dalam mengantisipasi berbagai kemungkinan resiko usaha yang telah dibiayainya. Untuk itu koperasi bobato unit sofifi selalu hati-hati dalam memberikan kredit kepada anggotanya dan menjaga kepercayaan dari masyarakat.

Koperasi Bobato Unit Sofifi senantiasa memperbaiki sistem pengendalian untuk memperkecil kemungkinan terjadinya kredit bermasalah. Tujuan pengendalian intern pinjaman tersebut adalah sebagai berikut:

a) Memastikan pinjaman yang diberikan kepada anggota/ peminjam yang tepat dan membutuhkan.

b) Jumlah pinjaman yang diberikan sesuai dengan kebutuhan dan kemampuan peminjam untuk mengembalikan.

c) Semua pinjaman yang diberikan ter-orientasi dan tercatat.

d) Seluruh penerimaan cicilan pinjaman yang diberikan dan bunganya tercatat dalam periode yang tepat.

e) Catatan atas pinjaman yang diberikan konsisten antara catatan dalam buku besar dan catatan dalam buku-buku pembantu. 
f) Semua pinjaman yang diberikan dilaporkan dan disajikan dengan nilai wajar didalam laporan keuangan.

g) Semua pinjaman yang diberikan dapat ditagih kembali berikut dengan jasa yang menjadi hak koperasi.

\section{Elemen Pengendalian Internal}

Elemen-elemen pengendalian internal dalam Koperasi Bobato Unit Sofifi

a. Lingkungan Pengendalian (Control Environmen)

Lingkungan pengendalian koperasi ini mencakup sikap para manajemen dan karyawan terhadap pentingnya pengendalian yang ada di organisasi tersebut. Seperti halnya bagian-bagian yang menangani masalah kredit yaitu bagian kredit, manager dan kasir. Salah satu faktor yang berpengaruh terhadap lingkungan pengendalian adalah manajemen (manajemen tunggal dalam persekutuan atau manajemen bersama yang sesuai dengan RAT) dan gaya operasi manajemen serta praktik kepersonaliaan.

b. Penilaian Resiko (Risk Assesment)

Suatu risiko yang telah di identifikasi dapat dianalisis dan evaluasi sehingga dapat di perkirakan intensitas dan tindakan apa yang perlu dilakukan untuk meminimalkan terjadinya kredit macet.

c. Prosedur Pengendalian (Control Procedure)

Prosedur pengendalian ditetapkan untuk menstandarisasi proses kerja sehingga menjamin tercapainya tujuan perusahaan dan mencegah atau mendeteksi terjadinya ketidakberesan dan kesalahan. Prosedur pengendalian meliputi hal-hal sebagai berikut:

- Personil yang kompeten

- Pelimpahan tanggung jawab

- Pemisahan tanggung jawab untuk setiap bagian, misalnya bagian kredit tidak ikut menangani bagian kasir atau pendanaan

- Pemisahan fungsi akuntansi, penyimpanan aset dan operasional

d. Pemantauan (Monitoring)

Pemantauan terhadap sistem pengendalian intern, apakah sistem yang telah ditetapkan sudah dijalankan sesuai dengan RAT. Pengendalian intern dapat dimonitor dengan baik dengan cara penilaian khusus. Usaha pemantauan yang terakhir dapat dilakukan dengan cara mengamati perilaku karyawan atau tanda-tanda peringatan yang diberikan oleh sistem akuntansi.

e. Informasi dan Komunikasi (Information and Communication)

Informasi tentang lingkungan pengendalian yaitu penilaian risiko, prosedur pengendalian dan monitoring.

\section{Prinsip Tata Kelola Perusahaan}

Dalam hal ini pihak Koperasi Bobato Unit Sofifi juga menerapkan prinsip-prinsip tata kelola yang baik agar kepercayaan masyarakat dapat dipertahankan dan bahkan ditingkatkan. Adapun prinsip-prinsip tersebut sebagai berikut:

a. Prinsip kepercayaan (Fiduciary Principle)

Setiap dana masyarakat yang disimpan Koperasi Bobato Unit Sofifi ini merupakan atas dasar kepercayaan, sehingga pihak Koperasi Unit Sofifi harus 
menjaga kesehatannya dan memelihara kepercayaan masyarakat padanya. Dengan cara lebih hati-hati dalam memberikan kredit kepada nasabah kreditur karena dana yang disalurkan melalui kredit tersebut berasal dari dana masyarakat yang dipercayakan kepadanya.

b. Prinsip kehati-hatian (Prudential Principle)

Untuk itu sebelum memberikan pembiayaan kepada nasabah Koperasi Bobato Unit Sofifi ini harus melakukan studi kelayakan terlebih dahulu. Dengan melaksanakan prinsip 5C dan 7P sebagai analisis pembiayaan yang akan diberikan kepada nasabah. Selain itu pihak koperasi juga berupaya meningkatkan kualitas para karyawannya, khususnya bagi mereka yang bertugas sebagai analisis kredit atau bagian yang menangani kredit.

\section{c. Prinsip kerahasiaan (Confidential Principle)}

Koperasi Bobato Unit Sofifi ini juga menerapkan prinsip kerahasiaan sebagai wujud perlindungan terhadap nasabah. Agar data-data nasabah aman dan juga untuk meningkatkan kepercayaan masyarakat terhadap Koperasi Bobato Unit Sofifi.

d. Mengenal nasabah (Know Your Customer Principle)

Dalam proses menerima nasabah baik pendanaan dan pinjaman pihak Koperasi Bobato Unit Sofifi selalu meminta data diri calon nasabah, berupa identitas diri, pekerjaan, sumber dana dan tujuan penggunaan dana. Setelah itu data-data tersebut diteliti misalnya dengan melakukan wawancara.

Informasi mengenai nasabah sebagaimana tersebut harus digali secara mendalam agar kredit yang disalurkan benar-benar tepat tidak mengalami masalah.

e. Prinsip tata kelola perusahaan yang baik (Good Corporate Governance Principle)

Dengan penerapan tata kelola perusahaan yang baik (Good Corporate Governance) sebagai salah satu upaya untuk memperkuat kondisi internal Koperasi Bobato Unit Sofifi Yang berlandaskan pada lima prinsip dasar yaitu:

1) Transparansi (transparency): keterbukaan dalam mengemukakan informasi yang relevan serta keterbukaan dalam melaksanakan proses pengambilan keputusan.

2) Akuntabilitas (accountability): kejelasan fungsi dan pelaksanaan pertanggung jawaban setiap bagian sehingga pengelolaannya berjalan secara efektif.

3) Pertanggungjawaban (responsibility): kesesuaian pengelolaan koperasi sesuai dengan Rapat Anggota Tahunan (RAT) dan prinsip-prinsip pengelolaan lembaga keuangan yang sehat.

4) Independesi (independency): mengelola koperasi secara profesional tanpa pengaruh dan tekanan dari pihak manapun.

5) Kewajaran (fairness): keadilan dan kesetaraan dalam memberikan bunga simpanan maupun bunga pinjaman berdasarkan Rapat Anggota Tahunan (RAT).

f. Prinsip tanggung jawab sosial perusahaan (Corporate Social Responsibility rinciple)

Kerjasama dan penyesuaian dengan lingkungan dilakukan oleh Koperasi Bobato Unit Sofifi dengan memberikan bantuan secara periodik kepada masyarakat. 
Dalam hal ini kegiatan religius, olahraga dan budaya pedesaan. Karena dalam SHU yang didapat tiap tahun diprogramkan untuk sosial sebesar 10\% (Mitra Koperasi, 2007:35).

Tabel 4.2 Tabel masalah

\begin{tabular}{|l|l|}
\hline Peminjam & Nasabah \\
\hline Kredit tidak lancar & 100 \\
\hline Kredit macet & 113 \\
\hline jumlah & $\mathbf{2 1 3}$ \\
\hline
\end{tabular}

Sumber: koperasi bobato unit sofifi.2016

Dari data tersebut dapat dikatakan bahwa sistem pengendalian internal yang diterapkan oleh Koperasi Bobato Unit Sofifi dengan Penerapan Prinsip 5C dan 7P yang secara garis besar tidak menutup kemungkinan kredit bermasalah.

\section{KESIMPULAN}

Pengendalian internal adalah proses yang dapat dipengaruhi manajemen dan karyawan dalam menyediakan secara layak suatu kepastian mengenai prestasi yang diperoleh secara objektif dalam penerapannya tentang bagian laporan keuangan yang dapat dipercaya, diterapkannya efisiensi dan efektivitas dalam kegiatan operasional perusahaan dan diterapkannya peraturan dan hukum yang berlaku agar ditaati oleh semua pihak. Praktiknya Koperasi Bobato Unit Sofifi hanya menerapkan jaminan dan karakter dalam 5C sedangkan dalam 7P hanya prospect, payment dan personality.

Selain itu juga diterapkan elemen-elemen pengendalian internal yaitu lingkungan pengendalian, penilaian resiko, prosedur pengendalian, pemantauan dan informasi dan komunikasi.

Dalam hal ini pihak Koperasi Bobato Unit Sofifi juga menerapkan prinsip-prinsip tata kelola yang baik agar kepercayaan masyarakat dapat dipertahankan dan bahkan ditingkatkan.

\section{Rekomendasi}

1. Tingkatkan kualitas pengendalian internal pemberian kredit agar kredit bermasalah atau kredit macet dapat diminimalisasi sekecil mungkin.

2. Terus tingkatkan kinerja yang sudah terprogram yang sesuai dengan RAT agar dapat survive sehingga dapat terus bersaing dengan lembaga keuangan yang lain. 


\section{DAFTAR PUSTAKA}

Baridwan, Zaki, 2002, Intermediate Accounting. Yogyakarta:BPFE.

Budhijayanto, Esa Dharmawan. 2012. Sistem Akuntansi Pemberian Kredit pada PD. BPR BKK Ungaran Kabupaten Semarang. Tugas Akhir Diploma III Akuntansi Universitas Negeri Semarang.

Candrayani. 2014. Evaluasi Sistem Informasi Akuntansi Pemberian Kredit studi kasus pada PT. Bank Rakyat Indonesia (Persero), Tbk Unit Sumbersari Cabang Banyuwangi. Skripsi Universitas Muhammadiyah Jember.

Eka Febriana Rosita. 2011. Analisa Prosedur Pemberian Kredit pada Koperasi Simpan Pinjam Artha Jaya Mandirimojokerto. Skripsi Universitas Gajahmada.

http://pustakaonline.com: Peranan Pengendalian Internal dalam Menunjang Efektivitas Sistem Pemberian Kredit Usaha Kecil dan Menengah, Kamis 10 Februari 2016.

http://sigmavite.blogspot.co.id/2012/01/koperasi-berdasarkan-sistem.html, $\quad$ Koperasi

Berdasarkan Sistem Perekonomian Masing-masing Negara, Kamis 12 Februari 2016

http://silapcity.blogspot.com. Kamis, 10 Februari 2016.

http://smecda.com/wp-content/uploads/2015/12/Permeneg-KUKM-2008-4.pdf, Peraturan Menteri Negara Koperasi dan Usaha Kecil dan Menengah Republik Indonesia Nomor : 21/PER/M.KUKM/XI/2008 Tentang pedoman Pengawasan Koperasi Simpan Pinjam dan Unit Simpan Pinjam Koperasi, Kamis 12 Februari 2016.

http://www.pustakaonline.com. Kamis, 10 Februari 2016.

Iqbal Hasan. 2002. Analisis Data Penelitian Dengan Statistik Jakarta: PT. Bumi Aksara.

Kasmir, 2003. Bank dan Lembaga Keuangan Lainnya, PT. Raya Grafindo Persada, Jakarta.

Kasmir. 2007. Manajemen Perbankan. Jakarta: PT. RajaGrafindo Persada.

Kasmir, 2009. Bank dan Lembaga Keuangan Lainnya, PT Raja Grafindo Persada. Jakarta.

Mulyadi. 2001. Sistem Akuntansi, Edisi Ketiga, Cetakan Ketiga. Jakarta:Salemba Empat.

Mulyono, Teguh Pudjo. 2001. Analisa Laporan Keuangan Untuk Perbankan. Jakarta: Djambatan

Niken Cahya Wijaya. 2011. Evaluasi Sistem Pengendalian Intern pemberian kredit pada KPRI Bina Sejahtera. Tugas Akhir Ahli Madya Diploma Akuntansi Keuangan Universitas Lampung.

Siagian, Sondang P. dalam Buku Nanang Fattah. 2007 Teori Pengembangan Organisasi. Jakarta: Bumi Aksara.

Sitti Maunah. 2010. Pengendalian Internal dalam Sistem Pemberian Kredit Pada Koperasi Simpan Pinjam Gradiska Candirejo. Tugas Akhir Ahli Madya Diploma III Ilmu Akuntansi Syariah Sekolah Tinggi Agama Islam Negeri (STAIN) Salatiga.

Sugiyono, 2005. Memahami Penelitian Kualitatif. Bandung: Alfabet.

Sugiyono, (2008). Metode Penelitian Kuantitatif Kualitatif dan R\&D. Bandung Alfabeta.

Sugiyono. 2009. Metode Penelitian Kuantitatif dan Kualitatif. CV.Alfabeta: Bandung.

Sugiyono. 2012. Memahami Penelitian Kualitatif. Bandung : ALFABETA.

TMbook. 2015. Sistem Informasi Akuntansi. Jakarta. Penerbit Andi.

Umar, Husein. 2005. Metode Penelitian untuk Skripsi dan Tesis Bisnis. Jakarta: PT.Raja Grafindo Persada

Undang-Undang Nomor 10 Tahun 1998 tentang Perubahan Undang-Undang Nomor 7 Tahun 1992. 